\title{
Effect of administration of progesterone and oestrogen on litter size in pigs
}

\author{
D. E. Wildt*, A. A. Culver†, C. B. Morcom and W. R. Dukelow
}

Endocrine Research Unit, Michigan State University, East Lansing, Michigan 48824, U.S.A.

\begin{abstract}
Summary. Progesterone and oestrone alone or in combination were administered to sows during early gestation. A dose of $25 \mathrm{mg}$ progesterone and $12.5 \mu \mathrm{g}$ oestrone injected together for 10,5 or 2 consecutive days during the implantation interval caused increased litter size at term.
\end{abstract}

The effect of exogenous steroid hormones on embryonic survival in the pig is unclear. While progesterone given alone during gestation has no, or even a detrimental effect on embryo viability (Sammelwitz, Dziuk \& Nalbandov, 1956; Haines, Warnick, Wallace \& Edwards, 1957; Spies, Zimmerman, Self \& Casida, 1959), the administration of progesterone and oestrogen has been reported to increase embryo survival (Reddy, Mayer \& Lasley, 1958; Day, Romack \& Lasley, 1963). The present studies were designed to determine the effect of steroid injections given at particular times during the first 23 days of gestation on litter size at term, and 2 trials were conducted.

\section{Trial I}

At Michigan State University, 183 multiparous sows of three genetic groups (Yorkshire, Hampshire, and Yorkshire-Hampshire crossbreds) were mated to 10 sires of the Yorkshire, Hampshire, or Duroc breeds. The experimental animals were from 18 to 30 months of age and $182-205 \mathrm{~kg}$ in weight. A complete $13.0 \%$ protein ration was fed at a rate $1.8 \mathrm{~kg} / \mathrm{animal} / \mathrm{day}$ throughout the mating and gestation periods.

Sows were mated on the first 2 days of oestrus, the first day of mating being Day 1 of gestation, and then observed daily for further evidence of oestrous behaviour. Experimental animals were assigned to one of ten treatment groups based on the breed of sow, parity of the sow and boar used. These standards were used to establish parity as a nonsignificant variable and to distribute breeds and boars as evenly as practicable throughout the treatment groups.

Progesterone ( $\Delta^{4}$-pregnen-3,20-dione: Sigma Chemical Co.) and oestrone $\left(\Delta^{1,3,5}(10)\right.$-estratrien3-ol-17-one: Sigma Chemical Co.) solutions were prepared as described by Reddy et al. (1958) and injected i.m. in volumes of 2 or $4 \mathrm{ml}$ at invervals of 23-25 hr. The control and hormone treatments used are shown in Table 1. Control animals received cottonseed oil at corresponding times of treatment administration, but because there were no differences in mean litter size in the various subgroups, these results were pooled into one control group (Group 0).

The number of sows returning to oestrus, the number carrying the litter to term and the total number of pigs farrowed were recorded. Mean litter size was calculated and statistically tested by least squares regression analysis (Harvey, 1960).

Conception rate was high in all treated sows and did not differ from that in controls. There was no effect of breed of sow or individual boar on litter size results (least squares regression analysis). As shown in Table 1, there was a significant increase in litter size when progesterone and oestrone were administered from Days 14-23 (Group 2), a period during which implantation is occurring (Green \& Winters, 1946). Administration of both steroids for shorter intervals at this time resulted in increased litter size only in Groups 4 and 6. There was no effect of treatment on the number of pigs stillborn.

\footnotetext{
* Present address: Institute of Comparative Medicine, Baylor College of Medicine, Texas Medical Center, Houston, Texas 77030, U.S.A.

$\dagger$ Present address: Department of Agriculture, Illinois State University, Normal, Illinois 61761, U.S.A.
} 
Table 1. The effect of various steroid treatments on mean litter size in pigs

\begin{tabular}{|c|c|c|c|c|c|}
\hline \multicolumn{4}{|c|}{ Treatment } & \multirow[b]{2}{*}{$\begin{array}{l}\text { No. of } \\
\text { sows }\end{array}$} & \multirow[b]{2}{*}{$\begin{array}{l}\text { Mean } \pm \text { S.E.M. no. } \\
\text { of young born }\end{array}$} \\
\hline Group & $\begin{array}{l}\text { Progesterone } \\
\text { (mg) }\end{array}$ & $\begin{array}{l}\text { Oestrone } \\
\quad(\mu g)\end{array}$ & Days & & \\
\hline 0 (control) & - & - & - & 39 & $10 \cdot 2 \pm 0 \cdot 42$ \\
\hline 1 & 25 & $12 \cdot 5$ & $4-13$ & 10 & $10.3 \pm 0.82$ \\
\hline 2 & 25 & $12 \cdot 5$ & $14-23$ & 13 & $12 \cdot 3 \pm 0.66^{*}$ \\
\hline 3 & 25 & $12 \cdot 5$ & $9-13$ & 11 & $9.8 \pm 0.83$ \\
\hline 4 & 25 & $12 \cdot 5$ & $14-18$ & 13 & $11.4 \pm 0.88 \ddagger$ \\
\hline 5 & 25 & $12 \cdot 5$ & $15-16$ & 16 & $10.7 \pm 0.66$ \\
\hline 6 & 25 & $12 \cdot 5$ & $16-17$ & 17 & $11.8 \pm 0.54 \dagger$ \\
\hline 7 & 50 & $25 \cdot 0$ & $14-23$ & 11 & $10.1 \pm 0.94$ \\
\hline 8 & - & $12 \cdot 5$ & $14-23$ & 10 & $9.9 \pm 0.73$ \\
\hline 9 & 25 & - & $14-23$ & 10 & $10.4 \pm 1.02$ \\
\hline
\end{tabular}

Significantly different from controls, ${ }^{*} P<0.02 ; \dagger P<0.05 ; \ddagger P<0.10$.

Since one extreme litter size can influence group means, the results were also examined on the basis of population distribution (Table 2). This was accomplished by representing the data as a function of the percentage of animals in each treatment group falling into one of five arbitrary litter size groups, based on a range of 9-11 (10.2 for control pigs, Table 1) for the average litter size, and applying a $\chi^{2}$ analysis. A normal population distribution was observed for Group 0 litters, but the distribution in Groups 2, 4 and 6 was altered. In Group 2 there was an increase in the percentage of sows producing litters of 12 or more pigs (Groups $\mathrm{D}+\mathrm{E}, P<0.05$ ) and $>13$ pigs (Group E, $P<0.01$ ). In Group 4 the proportion of sows producing litters of $>13$ was significantly different $(P<0.01)$ from that in Group 0 , but the distribution in Groups $D$ and B was inexplicable. A significant increase $(P<0.01)$ in the percentage of pigs with litter sizes of 12 or more was also found in Group 6, most of the effect resulting from the high proportion of animals in Group D. The remaining treatments in which steroids were given separately, at higher dosages or on Days 15 and 16 had no effect on mean litter size or population distribution when compared to control values.

Table 2. Percentage of sows in each treatment group in Trial I producing litters of 5 arbitrary sizes

\begin{tabular}{lcccccc}
\hline Group & $\begin{array}{c}\text { No. of } \\
\text { sows }\end{array}$ & $\begin{array}{c}\text { Group A } \\
(<7 / \text { litter })\end{array}$ & $\begin{array}{c}\text { Group B } \\
(7-8 / \text { litter })\end{array}$ & $\begin{array}{c}\text { Group C } \\
(9-11 / \text { litter })\end{array}$ & $\begin{array}{c}\text { Group D } \\
(12-13 / \text { litter })\end{array}$ & $\begin{array}{c}\text { Group E } \\
(>13 / \text { litter })\end{array}$ \\
\hline 0 (control) & 39 & 12.9 & $15 \cdot 4$ & $41 \cdot 0$ & $23 \cdot 0$ & $7 \cdot 7$ \\
2 & 13 & 0.0 & $0 \cdot 0$ & $38 \cdot 5$ & $23 \cdot 0$ & $38 \cdot 5$ \\
4 & 13 & 0.0 & $30 \cdot 7$ & $23 \cdot 1$ & $7 \cdot 7$ & $38 \cdot 5$ \\
6 & 17 & 5.9 & 0.0 & 23.5 & 52.9 & $17 \cdot 7$ \\
\hline
\end{tabular}

\section{Trial II}

This trial, conducted at Illinois State University, was limited by the number of animals available and utilized 33 multiparous sows (16-48 months of age, 160-230 kg in weight) of the Berkshire, Chester White, Hampshire or Chester White-Hampshire crossbred type. All animals were mated on the first 2 days of oestrus to one of four boars. Each sow was fed $1.8 \mathrm{~kg}$ of a $14.5 \%$ protein ration/day.

A double blind experiment was undertaken with two of the treatments (Groups 2 and 4) successful at Michigan being re-tested at Illinois. The control animals received only cottonseed oil. The mean $( \pm$ S.E.M.) litter size for sows $(\mathrm{N})$ in Groups 0,2 and 4 in Trial II were $9.6 \pm 0.85, N=10 ; 10.4 \pm 0.98$, $N=9 ; 11 \cdot 1 \pm 0.96, N=9$. The increased litter sizes observed for the steroid-treated sows were not significantly different from those of the control animals. Only 2 sows were available to test Treatment 6 ; litters of 14 and 15 were produced. 


\section{Discussion}

The results indicate that a progesterone toestrone treatment (ratio of $2000: 1$ ) imposed at the time of implantation in pigs can exert a beneficial effect on the litter size at term. The results of Trial I confirm the earlier studies of Reddy et al. (1958) who reported significant increases in litter size at Day 55 of gestation after treatment with progesterone and oestrone for 10 days during the 3 rd and 4th weeks of gestation. The results of Trial II are similar to those reported by Day et al. (1963) who observed a nonsignificant trend toward increased litter size at Day 25 of gestation in steroid-treated gilts. The present results suggest that the effect is related to the timing of the steroid injection and can result from as few as two injections given on Days 16 and 17.

The mechanism by which steroid administration exerts an effect on litter size is unknown. Daily injections of $25 \mathrm{mg}$ progesterone and $12.5 \mu \mathrm{g}$ oestrone during implantation (Days 14-23 of gestation) do affect plasma progesterone levels (D. E. Wildt \& W. R. Dukelow, unpublished data), which are higher than in control sows within $60 \mathrm{~min}$ and remain so during the treatment period. There is evidence that increasing the concentration of steroids can directly affect the embryo. Oestrogen can stimulate uptake and incorporation of amino acids in preimplantation mouse embryos through direct action on the blastocyst (Smith \& Smith, 1971). Perry, Heap \& Amoroso (1973) reported that blastocyst and trophoblast of the pig can synthesize oestrogens and progesterone in vitro and suggested a relationship between oestrogen synthesis and implantation in this species.

Progesterone and oestrogen regulate the production and secretion of specific uterine proteins in the pig which may be related to blastocyst development (Murray, Bazer, Wallace \& Warnick, 1972; Chen, Bazer, Cetorelli, Pollard \& Roberts, 1973; Knight, Bazer \& Wallace, 1973). In the present study steroid administration increased litter size only when initiated at least 14 days after oestrus and mating, a time similar to that reported when specific fractions and maximum production of uterine proteins occur in the cyclic gilt (Murray et al., 1972). It could be postulated that hormone administration at this time affects production of a substance which improves embryo viability.

We acknowledge the invaluable assistance of Dr H. D. Guthrie, C. Alan Wildt, Roger Hale, Joseph Strittmatter and David Snyder. This work was supported by a Cooperative Research Agreement with the USDA and NIH Research Career Development Award No. 1K4-HD35,300, Michigan Agricultural Experiment Station Journal Series No. 6608.

\section{References}

Chen, T.T., Bazer, F.W., Cetorelli, J., Pollard, W.E. \& RoBerts, R. (1973) Purification and properties of a progesterone-induced basic glycoprotein from the uterine fluids of pigs. J. Biol. Chem. 248, 8560-8566.

DAY, B.N., Romack, F.E. \& LASLeY, J.F. (1963) Influence of progesterone estrogen implants on early embryonic mortality in swine. J. Anim. Sci. 22, 637-639.

Green, W.W. \& Winters, L.M. (1946) Cleavage and attachment states of the pig. J. Morph. 78, 305-310.

Haines, C.E., Warnick, A.C., Wallace, H.D. \& EDWARDS, G.M. (1957) The effect of level of feeding and progesterone injections on reproductive performance in gilts. J. Amin. Sci. 16, 1099, Abstr.

HARVEY, W.R. (1960) Least squares analysis of data with unequal subclass numbers. Agricultural Research Services, USDA ARS 20-8.

KNight, J.W., Bazer, F.W. \& Wallace, H.D. (1973) Hormonal regulation of porcine uterine protein secretion. J. Amin. Sci. 36, 546-553.

Murray, F.A., JR, Bazer, F.W., Wallace, H.D. \& WARNICK, A.C. (1972) Quantitative and qualitative variation in the secretion of protein by the porcine uterus during the estrous cycle. Biol. Reprod. 7, 314-320.

Perry, J.S., Heap, R.B. \& Amoroso, E.C. (1973) Steroid hormone production by pig blastocysts. Nature, Lond. 245, 45-47.

Reddy, V.B., MAYer, D.T. \& LASley, J.F. (1958) Hormonal modification of the intrauterine environment in swine and its effect on embryonic viability. Res. Bull. Mo. agric. Exp. Stn 667, 5-31.

Sammelwitz, P.H., Dziuk, P.J. \& Nalbandov, A.V. (1956) Effect of progesterone on embryonal mortality of rats and swine. J. Anim. Sci. 15, 1211, Abstr. Sмгтн, D.M. \& Sмiтh, A.E.S. (1971) Uptake and incorporation of amino acids by cultured mouse embryos: estrogen stimulation. Biol. Reprod. 4, 6673.

Spies, H.G., Zimmerman, D.R., Self, H.L. \& Casida, L.E. (1959) The effect of exogenous progesterone on formation and maintenance of the corpora lutea and on early embryo survival in pregnant swine. $J$. Anim. Sci. 18, 163-171. 